\title{
Fungal F8-Culture Filtrate Induces Tomato Resistance against Tomato Yellow Leaf Curl Thailand Virus
}

\author{
Yi-Shu Chiu ${ }^{1}$, Yuh Tzean ${ }^{1}$, Yi-Hui Chen ${ }^{1,2}{ }^{2}$ Chi-Wei Tsai ${ }^{2}$ (D) and Hsin-Hung Yeh $1,3,4, * \mathbb{D}$ \\ 1 Agricultural Biotechnology Research Center, Academia Sinica, Taipei 11529, Taiwan; \\ abookchiu@gmail.com (Y.-S.C.); miketzean@gmail.com (Y.T.); yihui820123@gate.sinica.edu.tw (Y.-H.C.) \\ 2 Department of Entomology, National Taiwan University, Taipei 10617, Taiwan; chiwei@ntu.edu.tw \\ 3 Department of Plant Pathology and Microbiology, National Taiwan University, Taipei 10617, Taiwan \\ 4 Institute of Biotechnology, National Taiwan University, Taipei 10617, Taiwan \\ * Correspondence: hyeh@sinica.edu.tw; Tel.: +886-2-2787-2116
}

Citation: Chiu, Y.-S.; Tzean, Y.; Chen, Y.-H.; Tsai, C.-W.; Yeh, H.-H. Fungal F8-Culture Filtrate Induces Tomato Resistance against Tomato Yellow Leaf Curl Thailand Virus. Viruses 2021, 13, 1434. https://doi.org/ $10.3390 / \mathrm{v} 13081434$

Academic Editors: Yau-Heiu Hsu and K. Andrew White

Received: 11 June 2021

Accepted: 20 July 2021

Published: 23 July 2021

Publisher's Note: MDPI stays neutral with regard to jurisdictional claims in published maps and institutional affiliations.

Copyright: (C) 2021 by the authors. Licensee MDPI, Basel, Switzerland. This article is an open access article distributed under the terms and conditions of the Creative Commons Attribution (CC BY) license (https:// creativecommons.org/licenses/by/ $4.0 /)$.

\begin{abstract}
Tomato (Solanum lycopersicum) is an important economic crop worldwide. However, tomato production is jeopardized by the devastating tomato yellow leaf curl disease caused by whiteflytransmitted begomoviruses (WTBs). In this study, we evaluated the efficacy of our previously developed plant antiviral immunity inducer, fungal F8-culture filtrate, on tomato to combat tomato yellow leaf curl Thailand virus (TYLCTHV), the predominant WTB in Taiwan. Our results indicated that F8-culture filtrate treatment induced strong resistance, did not reduce the growth of tomato, and induced prominent resistance against TYLCTHV both in the greenhouse and in the field. Among TYLCTHV-inoculated Yu-Nu tomato grown in the greenhouse, a greater percentage of plants treated with F8-culture filtrate (43-100\%) were healthy-looking compared to the $\mathrm{H}_{2} \mathrm{O}$ control (0-14\%). We found that TYLCTHV cannot move systemically only on the F8-culture filtrate pretreated healthylooking plants. Tracking the expression of phytohormone-mediated immune maker genes revealed that F8-culture filtrate mainly induced salicylic acid-mediated plant immunity. Furthermore, callose depositions and the expression of the pathogen-induced callose synthase gene, POWDERY MILDEW RESISTANT 4 were only strongly induced by TYLCTHV on tomato pretreated with F8-culture filtrate. This study provides an effective way to induce tomato resistance against TYLCTHV.
\end{abstract}

Keywords: tomato yellow leaf curl disease; whitefly transmitted begomoviruses; tomato yellow leaf curl Thailand virus; virus resistance; plant immunity inducer

\section{Introduction}

Tomato (Solanum lycopersicum) is an economically important vegetable crop, which ranks third in this class in terms of volume of production and first in terms of processing volume [1]. However, tomato yellow leaf curl disease (TYLCD) caused by whitefly-transmitted begomoviruses (WTBs) has a devastating effect on tomato production worldwide [2-5]. One of the main approaches to managing TYLCD relies on controlling the whitefly vector using insecticide [6,7]. However, it has become increasingly difficult to control the whitefly vector population in this way because of the rapid evolution of whitefly's resistance to insecticides $[2,7,8]$.

Screening of TYLCD-resistant tomato cultivars revealed that most commercially cultivated tomato cultivars are susceptible to the disease [9]. To breed TYLCD-resistant cultivars, six TYLCD resistance gene loci (Ty gene family) were identified from wild tomato species [6,10-12]. However, the breeding process requires several backcross steps and is usually time consuming. As a large number of tomato cultivars are planted for commercial purposes, transferring the resistance loci to these various commercial tomato cultivars remains a challenge. Transgenic approaches that mainly use RNAi strategies have been successfully applied to plants to manage TYLCD infection with promising results [13-24]. However, the debate over using genetically modified organisms (GMO) in agriculture has 
hindered the distribution of these transgenic tomatoes. One way to address this issue would be to induce plant innate immunity to combat TYLCD.

Plant innate immunity consists of two distinctive pathways: microbe/pathogenassociated molecular pattern (MAMP/PAMP)-triggered immunity (PTI) and effectortriggered immunity (ETI) [25-29]. PTI is triggered by MAMPs/PAMPs via cell surfacelocalized pattern-recognition receptors (PRRs), whereas ETI is activated by pathogen effector proteins predominantly through direct or indirect perception of intracellular nucleotidebinding, leucine-rich repeat receptors (NLRs) [25,30-32]. At the first layer of plant innate immunity, PTI, signals are transmitted through activation of mitogen-activated protein kinases (MAPKs), inducing signaling and defense processes such as reactive oxygen species (ROS) production, ion fluxes, salicylic acid (SA) and ethylene (ET) accumulation, resistance gene activation such as genes encoding pathogenesis-related proteins (PRs), and callose deposition [33-38]. However, adapted pathogens can deliver diverse effectors into plant cells to interfere with PTI and enhance virulence [39-43]. To counteract the invasion, plants utilize intracellular polymorphic resistance $(\mathrm{R})$ proteins to perceive these effectors either through direct binding or monitoring perturbations of host proteins caused by effectors, to initiate a more robust defense ETI [29,44]. ETI often leads to hypersensitive response (HR), a type of programmed cell death that has been hypothesized to restrict pathogen growth at the local infection site [32,45-47].

The application of ETI in plant protection requires introduction of $\mathrm{R}$ protein into susceptible cultivars by breeding or transgenic approaches, which is time consuming, as mentioned above. In addition, WTBs evolve quickly which leads to the occurrence of resistance breaking strains as $\mathrm{R}$ protein usually recognizes specific effectors. In comparison to ETI, PTI can be induced in all cultivars, and has the potential to be applied to all tomato cultivars. Indeed, several plant immunity inducers from biological sources have been reported including proteins [48-53], oligosaccharides [54,55], microbial inducers [56-58], and oil and related compounds [59]. However, the application of plant immunity inducers on crop protection requires the need to overcome several challenges, such as the high cost of the inducers, effectiveness in plant protection, and reduced crop growth and quality $[60,61]$. Therefore, practical application of plant immunity inducers on crops for effective protection mostly remains to be explored.

In our previous study, we screened culture filtrates derived from soil microorganisms cultured with medium made of weeds and cheaply obtainable vegetables (may contain pathogen/damage-associated molecular patterns) for induction of effective plant defense against viruses [62]. We obtained a culture filtrate derived from Trichosporon sp. (F8-culture filtrate) that induced strong resistance to different viruses in various plants [62]. The infection rate of tobacco mosaic virus (TMV) reduced dramatically on Nicotiana benthamiana pretreated with F8-culture filtrate [62]. The symptoms were also considerably reduced on F8-culture filtrate-pretreated N. benthamiana and Brassica juncea inoculated with cucumber mosaic virus (CMV) and turnip mosaic virus (TuMV), respectively. A fraction of the polysaccharides, designated F8-polysaccharide, with estimated molecular weight of $4260-12,000 \mathrm{kDa}$ is responsible for induction of the plant antiviral immunity. The F8polysaccharide mainly induced priming of the SA immune pathway, and therefore, has great potential for application on tomato against viruses as previous reports have also indicated that SA-mediated plant immunity is important in tomato resistance to viral diseases including TYLCD [63].

In this study, we applied F8-culture filtrate to tomato to combat tomato yellow leaf curl Thailand virus (TYLCTHV), the predominant WTB in Taiwan [64-66]. Our results indicated that F8-culture filtrate treatment in tomatoes induced strong resistance to TYLCTHV both in the greenhouse and in the field. Furthermore, we resolved the main immune responses in F8-culture filtrate-treated tomato. Our results not only provide an effective method to manage TYLCD, but also provide important knowledge for further design strategies to combat the effect of WTBs on crops. 


\section{Materials and Methods}

\subsection{Whiteflies, Virus and Plants}

The sources of our whitefly (Bemisia tabaci Middle East-Asia Minor 1, MEAM1) and TYLCTHV isolate Ly5 (GenBank Accession No. GU723742 and GU723754) are described in Weng et al. [67].

The non-viruliferous whitefly was reared on Chinese kale (Brassica oleracea cv. Alboglabra Group) in whitefly-proof net cages $\left(30 \times 30 \times 30 \mathrm{~cm}^{3}\right)$ at $26{ }^{\circ} \mathrm{C}$, under a $16-\mathrm{h}$ light/8-h dark cycle.

TYLCTHV isolate Ly5 was maintained, as previously described [68], in tomato plants (Solanum lycopersicum $\mathrm{cv}$. ANT22) and used for vector transmission, using B. tabaci, under the aforementioned conditions.

Tomato cultivar Yu-Nu (S. lycopersicum) was purchased from Known-You Seed (Kaohsiung, Taiwan), and grown and maintained in a glass-covered greenhouse. Xiao-Nu (S. lycopersicum) was purchased from Known-You Seed and maintained in the field (Alian District, Kaohsiung City, Taiwan) for field analysis.

\subsection{Treatment and Inoculation}

Yu-Nu tomatoes (2-3 weeks after sowing) were sprayed with $\mathrm{H}_{2} \mathrm{O}$ (0.4 mL per plant) or F8-culture filtrate ( $0.4 \mathrm{~mL}$ per plant) for a total of three times with a 24 -h interval between each spray as previously described [62]. Twenty-four hours after the final treatment, plants were inoculated with TYLCTHV by viruliferous B. tabaci as previously described [69] with modifications. Briefly, non-viruliferous $B$. tabaci was transferred to the net cage enclosed with TYLCTHV-infected ANT22 tomato and allowed 3-day acquisition access periods (AAP). The viruliferous $B$. tabaci was used to inoculate tomato plants through feeding for $96 \mathrm{~h}$ (approximately 20 whiteflies on one leaf per plant). The inoculated-leaves were cut and collected at $4 \mathrm{dpi}$. The number of replicated experimental sets and the number of biological replicates for each assay are specified in the Results section.

\subsection{Disease Index for Evaluation of Tomato Yellow Leaf Curl Disease (TYLCD)}

Tomatoes were evaluated for TYLCD severity according to a disease index of 5 levels. Level $0=$ no visible symptoms, inoculated plants show the same growth and development as non-inoculated plants; Level 1 = slight yellowing and minor curling of leaflet ends; Llevel $2=$ wide range of leaf yellowing, curling and cupping, with some reduction in size; Level 3 = wide range of leaf yellowing, pronounced leaf cupping and curling; Level $4=$ very severe plant stunting and leaf yellowing, pronounced leaf cupping and curling, and plant ceased to grow.

\subsection{Nucleic Acid Isolation and Gene Expression Analysis}

Total DNA and RNA were extracted using an optimized CTAB method [70]. Leaf tissue $(100 \mathrm{mg})$ was frozen with liquid nitrogen and ground into a fine powder with a pestle and mortar. The powder was then dissolved in $750 \mu \mathrm{L}$ of CTAB buffer $(2 \% \mathrm{CTAB}$, $2 \%$ PVP, $2.0 \mathrm{M} \mathrm{NaCl}, 0.1 \mathrm{M}$ Tris-HCl, $25 \mathrm{mM}$ EDTA, $4 \%$-mercaptoethanol) and incubated at $65{ }^{\circ} \mathrm{C}$ for $30 \mathrm{~min}$. Next, $750 \mu \mathrm{L}$ of chloroform:IAA (24:1) was added to the mixture and centrifuged at $16,000 \times g$ for $10 \mathrm{~min}$. To precipitate DNA and RNA, the upper phase was transferred to a new tube, mixed with 2 volumes of ethanol $(99.9 \% v / v)$ and $1 / 4$ volume of $10 \mathrm{M} \mathrm{LiCl}$, and centrifuged at $16,000 \times g$ for $10 \mathrm{~min}$. The DNA and RNA supernatant were discarded and the pellet was washed with $1 \mathrm{~mL}$ of ethanol $(70 \% v / v)$. After centrifugation, the supernatant was discarded and the pellet was dissolved in $200 \mu \mathrm{L}$ nuclease-free water (Invitrogen, Carlsbad, CA, USA).

Residual DNA was removed by using the TURBO DNA-free kit (Ambion, Austin, TX, USA) before RT-PCR. cDNA was synthesized by using the PrimeScript RT-PCR Kit (Takara Bio, Shiga, Japan). Quantitative PCR (q-PCR) and quantitative reverse transcription PCR (qRT-PCR) were conducted with the SYBR protocol (Life Technologies, Carlsbad, CA, USA) and the ABI 7100 real-time PCR system (Applied Biosystems, Carlsbad, CA, 
USA). For quantitative analysis, the common tomato endogenous control, $\beta$-actin [71-73], was verified for expression stability among different samples and the primer efficiency compared to specified target gene(s) was conducted prior to use. Relative fold change in DNA expression was determined by calculating $2^{-\Delta \Delta \mathrm{Ct}}$. The sequences of primers used for analysis are listed in Table S1.

\subsection{Measurement of Tomato Plant Fresh Weight}

Tomato Yu-Nu (3 weeks after sowing) were pretreated with $\mathrm{H}_{2} \mathrm{O}$ or F8-culture filtrate as mentioned above. All shoot tissues of individual plants were measured for fresh weight.

\subsection{Staining of Callose Depositions}

The tomato plants were pretreated with either $\mathrm{H}_{2} \mathrm{O}$ or F8-culture filtrate. Leaf samples were collected $24 \mathrm{~h}$ post treatment. One leaf per plant $(n=7)$ with similar growth stage were collected for each treatment group. In addition, for inoculation, viruliferous $B$. tabaci was used to inoculate on 1 leaf per tomato plant. One inoculated leaf per plant $(n=7)$ was also collected at 4 days post inoculation for staining of callose deposits. The collected leaves were fixated and de-stained with 1:3 of acetic acid (100\%)/ethanol (100\%) overnight. After washing in $150 \mathrm{mM} \mathrm{K}_{2} \mathrm{HPO}_{4}$ for $30 \mathrm{~min}$, leaves were incubated for $2 \mathrm{~h}$ in staining solution ( $150 \mathrm{mM} \mathrm{K}_{2} \mathrm{HPO}_{4}$ and $0.01 \%$ aniline blue). Zeiss Imager $\mathrm{Z1}$ fluorescence microscope (Carl Zeiss AG, Oberkochen, Germany) using a DAPI filter was used for imaging. The microscopic field photos were printed and the number of callose depositions were counted manually.

\subsection{Field Trial}

The field trials were conducted in Yuchi Township, Nantou County, Taiwan, and Alian District, Kaohsiung City, Taiwan. Three-week-old (after sowing) Yu-Nu and Xiao-Nu tomato cultivar seedlings were sprayed with $\mathrm{H}_{2} \mathrm{O}$ or F8-culture filtrate 3 times with a $24 \mathrm{~h}$ interval between each spray. Twenty-four hours after the final treatment, plants were transferred to an open field located at the specified location. The tomato plants were evaluated for disease severity at 2 months after transplantation. Evaluation of disease severity was conducted manually and recorded for each tomato plant based on 5 levels in disease index (see 2.3 Disease Index for Evaluation of Tomato Yellow Leaf Curl Disease and Figure S1).

\section{Results}

\subsection{F8-Culture Filtrate Induced Virus Resistance in Tomato Cultivar Yu-Nu}

To analyze whether F8-culture filtrate can induce tomato resistance against WTBs, we selected the cherry tomato cultivar, $\mathrm{Yu}-\mathrm{Nu}$, for analysis. $\mathrm{Yu}-\mathrm{Nu}$ tomato is a favorable tomato with commercial value; however, it is known for its susceptibility to several pathogens including WTBs. Initially, we conducted our experiments in a greenhouse. We used the whitefly vector, Bemisia tabaci, as a vector to transmit the TYLCTHV from infected tomato to $\mathrm{Yu}-\mathrm{Nu}$. $\mathrm{Yu}-\mathrm{Nu}$ tomatoes were pretreated with $\mathrm{H}_{2} \mathrm{O}$ or F8-culture filtrate by spraying consecutively three times with a $24 \mathrm{~h}$ interval between each spray. All pretreated plants were inoculated with TYLCTHV by using whitefly vector at $24 \mathrm{~h}$ post treatment (hpt). The disease severity was scored using an established disease index (Figure S1) on all TYLCTHVinoculated plants at 28 days post inoculation (dpi). In our 3 repeated sets of experiments (Exp. 1, 2, and 3), we analyzed 6-7 plants per treatment group $\left(\mathrm{H}_{2} \mathrm{O}\right.$ or F8-culture filtrate pretreatment) in each of the experimental sets (Figure 1). Most $\mathrm{H}_{2} \mathrm{O}$ pretreated plants showed more severe symptoms than the F8-culture filtrate pretreated group (Figure 1). Healthy-looking (Disease Index 0) plants were observed more in the F8-culture filtrate pretreated group compared to the $\mathrm{H}_{2} \mathrm{O}$ pretreated plants (Figure 1A,C,E and Figure S2). 


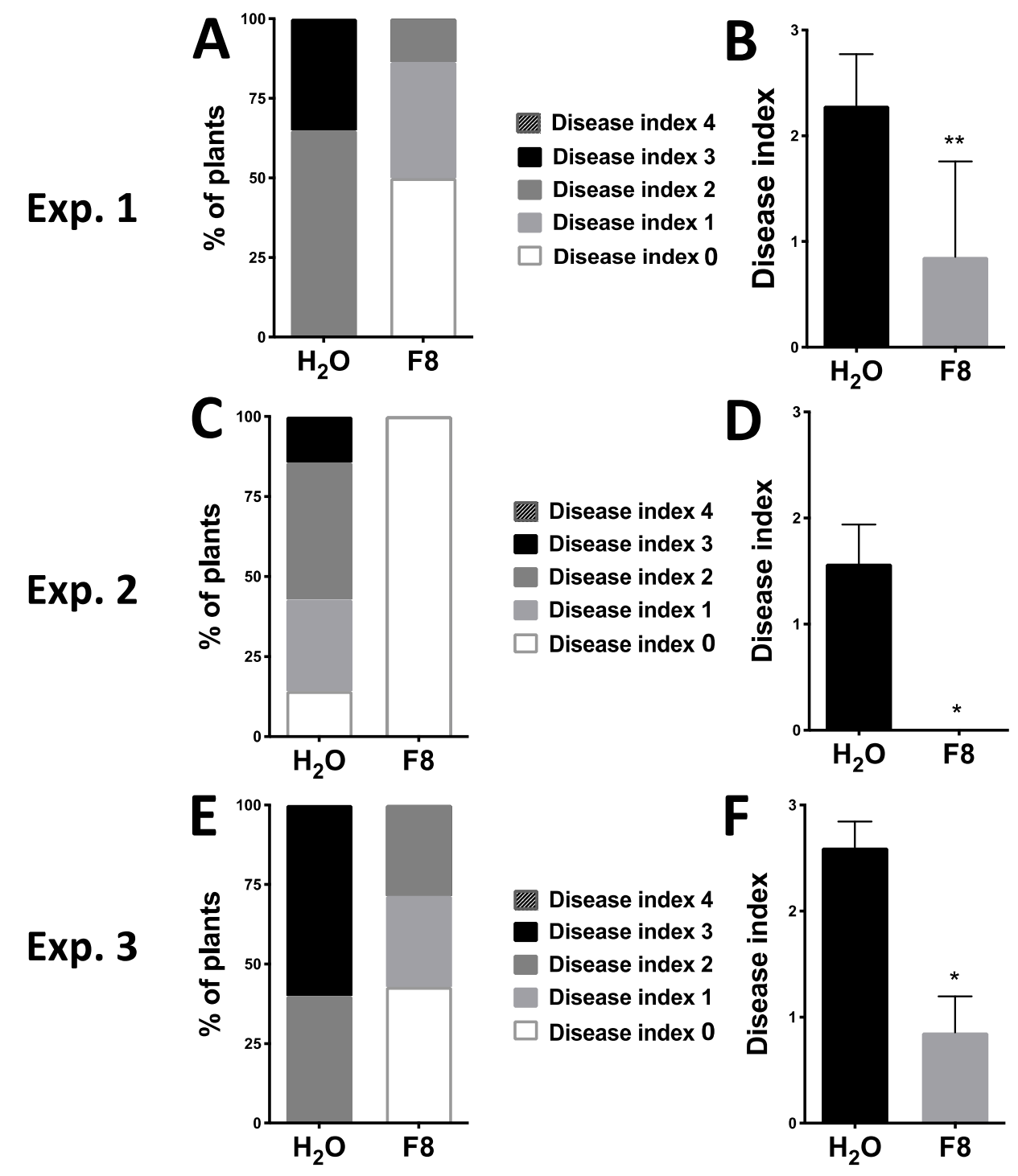

Figure 1. Symptoms on $\mathrm{H}_{2} \mathrm{O}$ or F8-culture filtrate pretreated $\mathrm{Yu}-\mathrm{Nu}$ tomato plants inoculated with tomato yellow leaf curl Thailand virus (TYLCTHV). The level of disease index was recorded at 28 days post inoculation (dpi) in the $\mathrm{H}_{2} \mathrm{O}$ or F8-culture filtrate pretreated group $(\mathbf{A}, \mathbf{C}, \mathbf{E})$. The average disease index of plants inoculated with TYLCTHV according to the specified pretreatment groups $(\mathbf{B}, \mathbf{D}, \mathbf{F})$. Data represent mean $\pm \mathrm{SEM} ; n=6-7$ biological replicates. Student's $t$-test was used for comparative analysis of the data for the F8-culture filtrate pretreated group and the $\mathrm{H}_{2} \mathrm{O}$ pretreated control group. ${ }^{*} p<0.05 ;{ }^{* *} p<0.01$.

From the same 3 sets of experiments (Exp. 1,2, and 3), the inoculated leaf and one systemic leaf from each plant $(n=6-7)$ were collected for evaluation of TYLCTHV accumulation in the $\mathrm{H}_{2} \mathrm{O}$ or F8-culture filtrate pretreated group. The relative accumulation of TYLCTHV genomic DNAs, DNA-A and -B, were quantified by quantitative PCR (qPCR). The results showed that TYLCTHV DNAs could be detected in inoculated leaves on plants pretreated with $\mathrm{H}_{2} \mathrm{O}$ or F8-culture filtrate (Figure 2A,B,E,F,I,J). On systemic leaves, TYLCTHV DNAs can be detected for both $\mathrm{H}_{2} \mathrm{O}$ or F8-culture filtrate pretreated plants that showed disease symptoms (Figure $1 \mathrm{~A}, \mathrm{C}, \mathrm{E}$ and Figure $2 \mathrm{C}, \mathrm{D}, \mathrm{G}, \mathrm{H}, \mathrm{K}, \mathrm{L}$ ). However, TYLCTHV could not be detected on F8-culture filtrate pretreated healthy-looking plants (Figure 2C,G,K). Of note, even though we could observe healthy-looking plants in the $\mathrm{H}_{2} \mathrm{O}$ pretreated group in Exp. 2 (Figure 1C), we could still detect TYLCTHV on the systemic leaves of these plants (Figure 2G). The experiments were repeated for 3 times with similar results. 

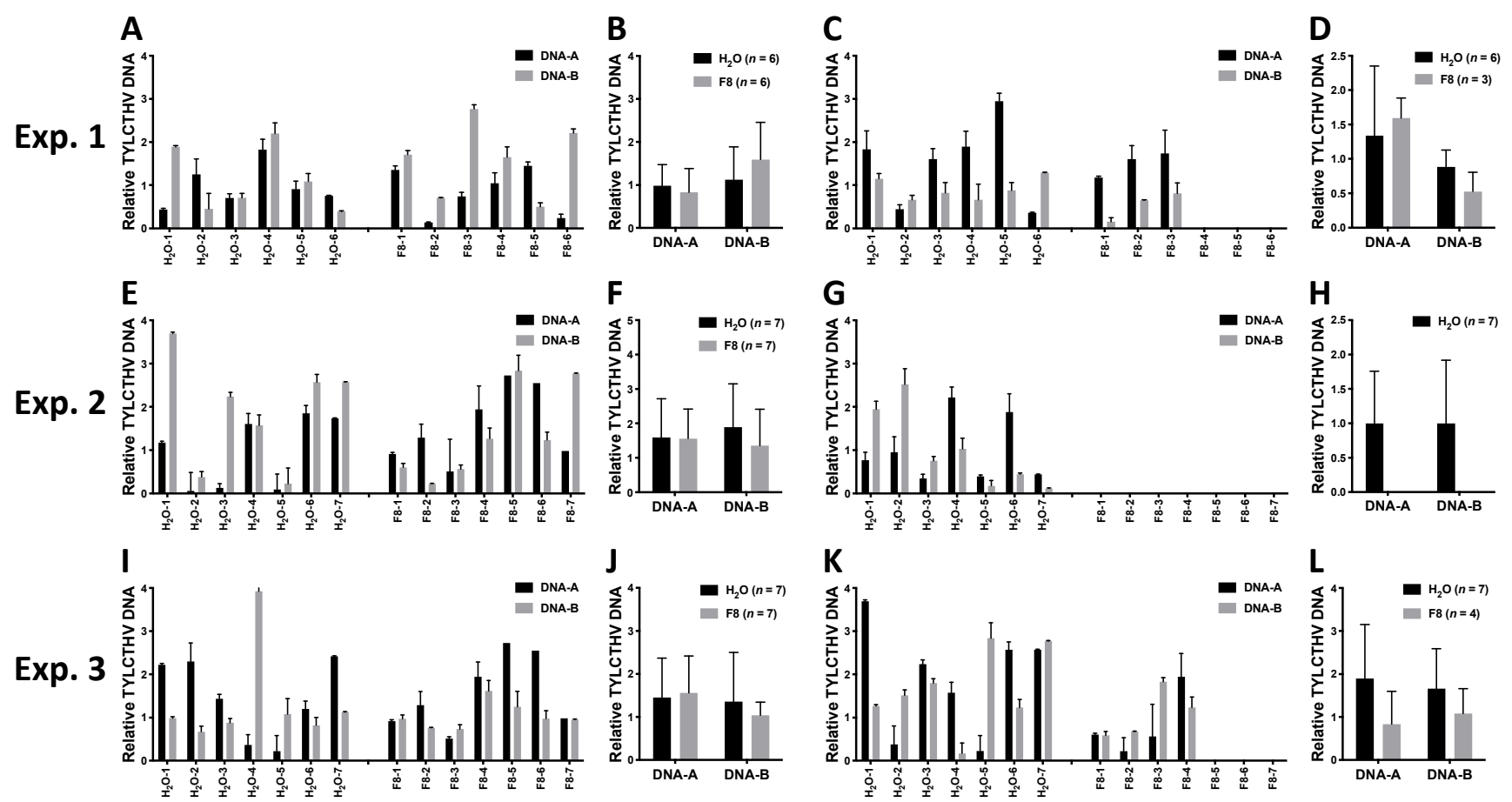

Figure 2. Quantification of TYLCTHV genomic DNA in inoculated tomato plants pretreated with F8-culture filtrate or $\mathrm{H}_{2} \mathrm{O}$. Relative TYLCTHV DNA level was quantified from $\mathrm{H}_{2} \mathrm{O}$ or F8-culture filtrate pretreated plants corresponding to Exp. 1, 2, and 3 in Figure 1 by qPCR analysis. TYLCTHV DNA was detected from individual samples of TYLCTHV-inoculated leaves $(\mathbf{A}, \mathbf{E}, \mathbf{I})$ or systemic leaves $(\mathbf{C}, \mathbf{G}, \mathbf{K})$. Three technical replicates were performed for all samples. Data represent mean \pm SEM. $\beta$-actin was used as an input control. The average of TYLCTHV DNA detected from (A,E,J) are shown in (B,F,J), respectively. The average of TYLCTHV DNA detected from $(\mathbf{C}, \mathbf{G}, \mathbf{K})$ are shown in $(\mathbf{D}, \mathbf{H}, \mathbf{L})$, respectively. Data represent mean \pm SEM; $n=3-6$ biological replicates. $\beta$-actin was used as an input control. Student's $t$-test was used for comparative analysis of the data for the F8-culture filtrate pretreated group and the $\mathrm{H}_{2} \mathrm{O}$ pretreated control group.

\subsection{Mock and F8-Culture Filtrate Treated Plants Show Similar Fresh Weight}

To determine whether F8-culture filtrate treatment affects the fresh weight in tomato, 3-week-old $\mathrm{Yu}-\mathrm{Nu}$ were pretreated with $\mathrm{H}_{2} \mathrm{O}$ or F8-culture filtrate as mentioned above and analyzed the fresh weight of the tomato plants 5 weeks post treatment. We conducted 2 sets of experiments and analyzed 8-11 plants per treatment $\left(\mathrm{H}_{2} \mathrm{O}\right.$ or F8-culture filtrate) in each of the experimental sets. We found that $\mathrm{H}_{2} \mathrm{O}$ and $\mathrm{F} 8$-culture filtrate-treated tomato showed similar fresh weight in our 2 replicated sets of experiments (Figure 3 and Figure S3).

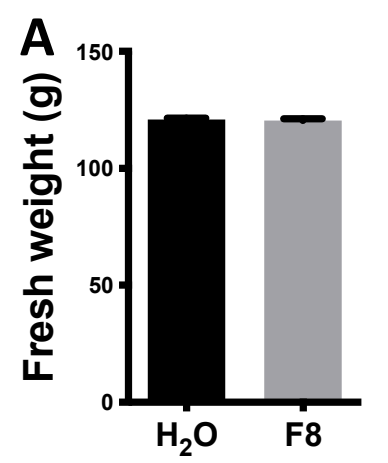

$\begin{array}{lll}\text { B } & \mathrm{H}_{2} \mathrm{O} & \mathrm{F} 8\end{array}$

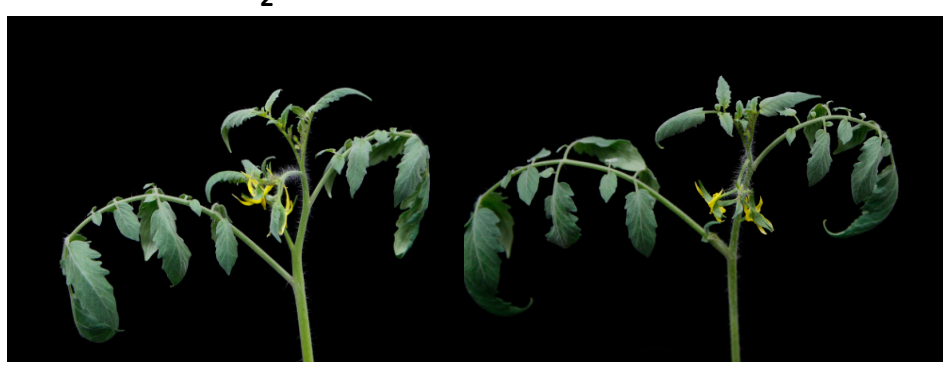

Figure 3. Fresh weight of $\mathrm{Yu}-\mathrm{Nu}$ tomato with $\mathrm{H}_{2} \mathrm{O}$ or F8-culture filtrate pretreatment. (A) The average fresh weight was recorded for each treatment group $(n=11)$. (B) The phenotype of $\mathrm{H}_{2} \mathrm{O}$ or F8-culture filtrate at 5 weeks post treatment. 


\subsection{F8-Culture Filtrate Mainly Induced the Expression of SA-Responsive Immune Marker Genes} on Tomato Cultivar $\mathrm{Yu}-\mathrm{Nu}$

To understand the possible immune pathways involved in F8-culture filtrate-induced resistance against TYLCTHV, we detected the expression of phytohormone-responsive immune marker genes. A comparison of the F8-culture filtrate and $\mathrm{H}_{2} \mathrm{O}$ pretreated $\mathrm{Yu}-\mathrm{Nu}$ tomato showed that the expression of SA-responsive immune marker gene, $P R-1$, increased 12.4-fold at $6 \mathrm{hpt}$, and was robustly induced by TYLCTHV to 82.8 -fold at 4 dpi (Figure 4A). In addition, the expression of $P R-5$ increased 12.2-fold at $6 \mathrm{hpt}$, robustly increased 8.1-fold at $12 \mathrm{hpt}$, with the induction gradually decreasing to 6.1 -fold at $24 \mathrm{hpt}$. Of note, after TYLCTHV infection, the PR-5 expression remained higher in F8-culture filtrate than $\mathrm{H}_{2} \mathrm{O}$ pretreated $\mathrm{Yu}-\mathrm{Nu}$ tomatoes, but the induction fold was not as prominent as at 6,12 and 24 hpt (Figure 4B).
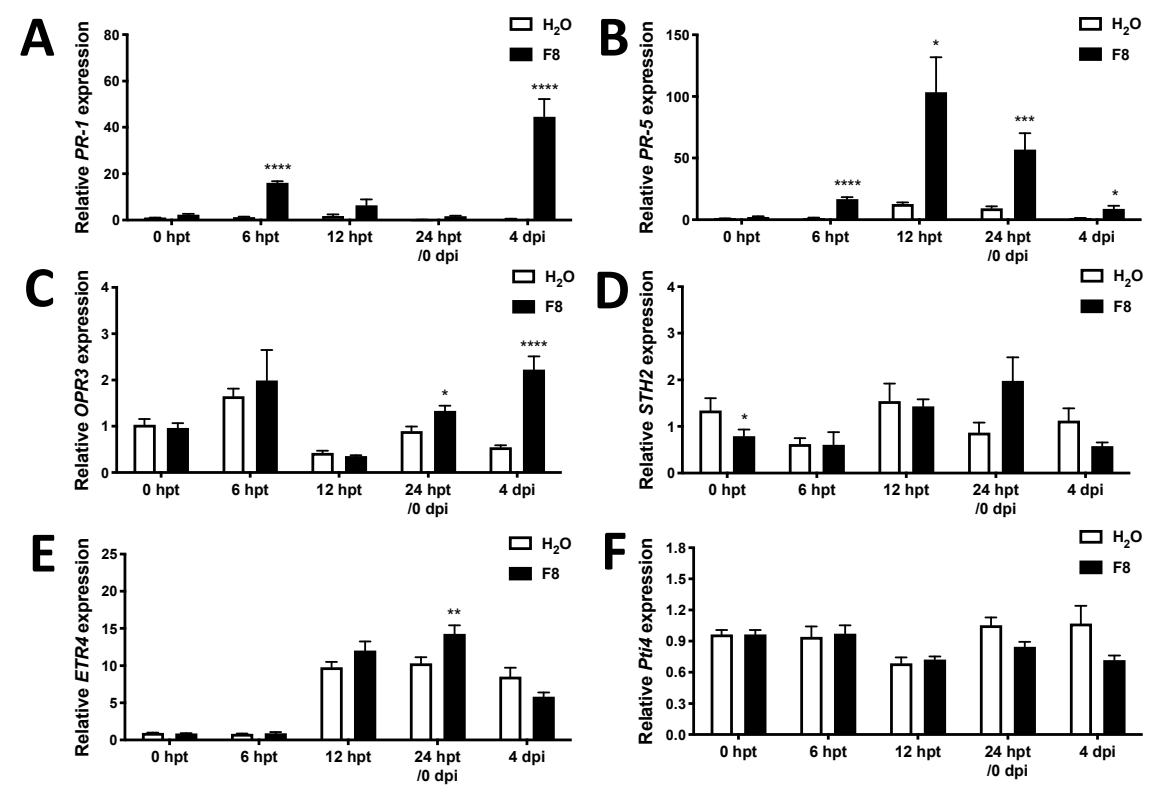

Figure 4. The expression of phytohormone-mediated immune marker genes in F8-culture filtrate or $\mathrm{H}_{2} \mathrm{O}$ pretreated $\mathrm{Yu}-\mathrm{Nu}$ tomato before or after TYLCTHV inoculation. Tomato plants were pretreated with $\mathrm{H}_{2} \mathrm{O}$ or F8-culture filtrate and inoculated with TYLCTHV using whitefly vector at $24 \mathrm{hpt}$. The relative expression of SA-responsive gene PR-1 (A) and PR-5 (B), jasmonic acid (JA)-biosynthesis gene OPR3 (C), JA-responsive gene STH2 (D), and ethylene (ET)-responsive gene ETR4 (E) and Pti4 (F) were detected by qRT-PCR at 0, 12 and $24 \mathrm{hpt}$ or at $4 \mathrm{dpi}$. $\beta$-actin was used as an input control. Data are mean \pm SEM of 3 biological replicates. Student's $t$-test was used for comparative analysis of the data for the $\mathrm{H}_{2} \mathrm{O}$ and F8-culture filtrate pretreated groups. ${ }^{*} p<0.05 ;{ }^{* *} p<0.01,{ }^{* * *} p<0.005,{ }^{* * *} p<0.001$.

In F8-culture filtrate-pretreated $\mathrm{Yu}-\mathrm{Nu}$ tomato, we found that the expression of JAresponsive immune marker gene, OPDA reductase 3 (OPR3) [74], was increased at $24 \mathrm{hpt}$ (1.5 fold) and $4 \mathrm{dpi}$ ( 4.1 fold) (Figure $4 \mathrm{C}$ ) compared to $\mathrm{H}_{2} \mathrm{O}$ pretreated $\mathrm{Yu}-\mathrm{Nu}$ tomato, but the induction of another JA-responsive immune marker gene, STH2 [75], was not observed in $\mathrm{H}_{2} \mathrm{O}$ or F8-culture filtrate-pretreated $\mathrm{Yu}-\mathrm{Nu}$ with or without TYLCTHV infection (Figure 4D).

Two ethylene (ET)-responsive immune marker genes, ethylene receptors-4 (ETR4) [76] and tomato transcription factor Pti4 [77], were also selected for analysis. The results showed that ETR4 only increased in F8-culture filtrate-pretreated $\mathrm{Yu}-\mathrm{Nu}$ as compared to the $\mathrm{H}_{2} \mathrm{O}$ pretreated $\mathrm{Yu}-\mathrm{Nu}$ control at $24 \mathrm{dpi}$ (1.4 Fold) (Figure 4E), and the induction of Pti4 was not observed in $\mathrm{H}_{2} \mathrm{O}$ or F8-culture filtrate pretreated $\mathrm{Yu}-\mathrm{Nu}$ with or without TYLCTHV infection (Figure 4F). 


\subsection{F8-Culture Filtrate Induced Callose Deposition on TYLCTHV-Inoculated Tomato Cultivar $Y u-N u$}

To understand how plants pretreated with F8-culture filtrate confine TYLCTHV infection (Figure 2), we analyzed whether callose deposition occurred in the tomato plants. Leaves were randomly collected from $\mathrm{H}_{2} \mathrm{O}$ or F8-culture filtrate pretreated plants at $24 \mathrm{hpt}$ and stained with $0.2 \%$ aniline blue (Figure $5 \mathrm{~A}, \mathrm{~B}$ ). In addition, we also collected leaves from plants pretreated with $\mathrm{H}_{2} \mathrm{O}$ or F8-culture filtrate with TYLCTHV inoculation at 4 dpi for staining (Figure 5C,D). Fluorescence microscopy was used to examine the callose deposition under UV illumination. All images were used for quantification of callose deposition. We observed limited callose deposition on $\mathrm{H}_{2} \mathrm{O}$ or F8-culture filtrate pretreated plants at $24 \mathrm{hpt}$ (Figure 5A,B,E). On TYLCTHV inoculated leaves, a limited number of callose depositions were observed on leaves pretreated with $\mathrm{H}_{2} \mathrm{O}$ (Figure $5 \mathrm{C}, \mathrm{E}$ ), but more profound callose depositions were observed only on leaves of plants pretreated with F8-culture filtrate (Figure 5D,E).
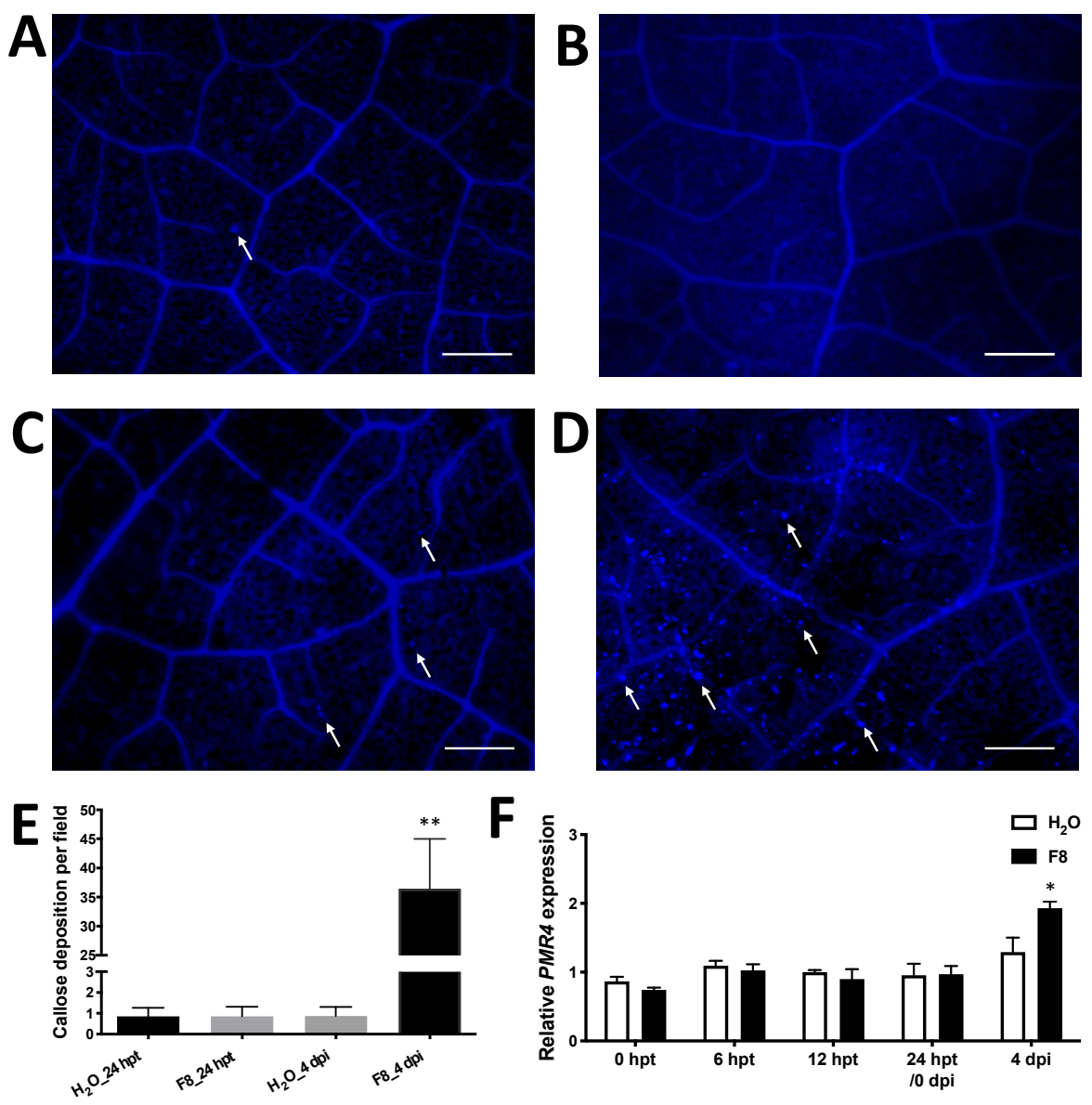

Figure 5. Staining of callose deposition in F8-culture filtrate or $\mathrm{H}_{2} \mathrm{O}$ pretreated $\mathrm{Yu}-\mathrm{Nu}$ tomato before or after TYLCTHV inoculation. Tomato plants were pretreated with $\mathrm{H}_{2} \mathrm{O}(\mathbf{A}, \mathbf{C})$ or F8-culture filtrate $(\mathbf{B}, \mathbf{D})$. The pretreated plants were inoculated with TYLCTHV using whitefly vector at $24 \mathrm{hpt}$. The callose deposition was stained with $0.02 \%$ aniline blue. Callose depositions were analyzed at $24 \mathrm{hpt}$ without TYLCTHV infection (A,B) or with TYLCTHV infection at $4 \mathrm{dpi}(\mathbf{C}, \mathbf{D})$ using a Zeiss Imager Z1 fluorescence microscope. Scale bar $=200 \mu \mathrm{m}$. White arrow indicates callose depositions. (E) The average numbers of callose deposition per field. Two pictures were taken per leaf (TYLCTHV-inoculated) collected from each plant ( $n=7$ plants) from $\mathrm{H}_{2} \mathrm{O}$ or F8-culture filtrate treatment for analysis. Data shows mean number of callose deposition per field $\pm \mathrm{SEM}$. Student's $t$-test was used to analyze the data from the F8-culture filtrate pretreated group and the $\mathrm{H}_{2} \mathrm{O}$-pretreated control group. ${ }^{* *} p<0.01$. (F) The relative expression of callose synthase gene PMR4 was detected by qRT-PCR at 0,12 and $24 \mathrm{hpt}$ without TYLCTHV infection or with TYLCTHV infection at $4 \mathrm{dpi}$. Data are mean \pm SEM from 3 plants. $\beta$-actin was used as an input control. Student's $t$-test was used for comparative analysis of the data in the $\mathrm{H}_{2} \mathrm{O}$ and F8-culture filtrate pretreated groups. ${ }^{*} p<0.05$. 
In addition to the staining of callose deposition, we also analyzed the expression of the pathogen-induced callose synthase gene, POWDERY MILDEW RESISTANT 4 (PMR4) [78]. Nucleic acids were extracted from collected leaves as mentioned above for callose staining. Significant induction of PMR4 was only observed on leaves of plants pretreated with F8-culture filtrate following TYLCTHV inoculation at 4 dpi (Figure 5F). The expression of PMR4 is consistent with the staining of callose deposition.

\subsection{F8-Culture Filtrate Induced Virus Resistance on Tomato Cultivar Yu-Nu and Xiao-Nu in the Field}

To analyze the effect of F8-culture filtrate on tomato against WTBs, we conducted two double-blind field trials on $\mathrm{Yu}-\mathrm{Nu}$ and Xiao-Nu. The first field trial was conducted in Nantou County, and the data were recorded after planting in the field for 2 months. The results showed that much milder symptoms were observed on tomato cultivar $\mathrm{Yu}-\mathrm{Nu}$ pretreated with F8-culture filtrate than with $\mathrm{H}_{2} \mathrm{O}$ pretreatment (Figure 6A,B).
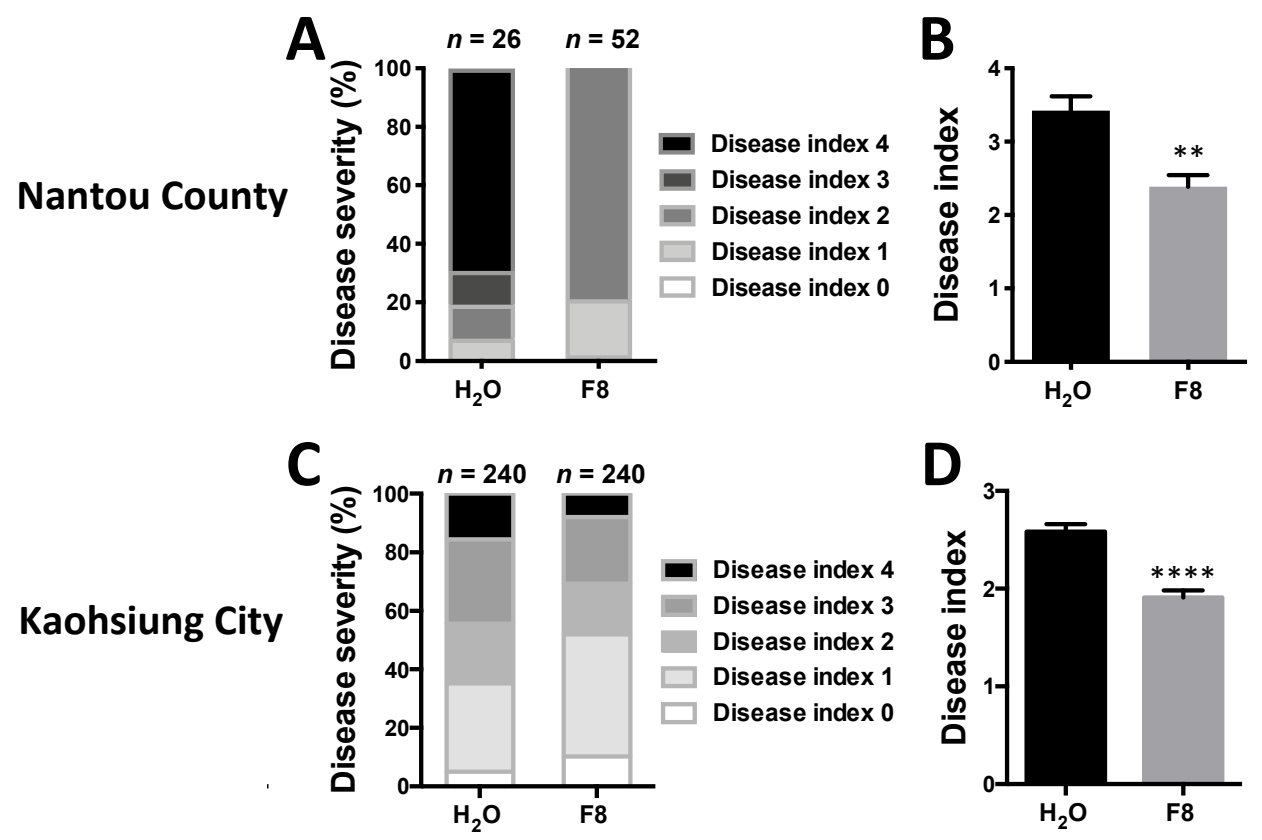

Figure 6. Symptoms on $\mathrm{H}_{2} \mathrm{O}$ or F8-culture filtrate treated tomato in the field in Nantou County and Kaohsiung City. Tomato seeds were sown and grown in a growth chamber for 3 weeks. Yu-Nu tomato and Xiao-Nu tomatoes were pretreated with $\mathrm{H}_{2} \mathrm{O}$ or F8 by spraying three times with a 24-h interval between each spray, then transplanted to fields in Yuchi Township, Nantou County, or Alian Dist., Kaohsiung City. The level of disease index was recorded at 2-months post transplantation $(\mathbf{A}, \mathbf{C})$. The average of the disease index (B,D). Data represent mean \pm SEM. Student's $t$-test was used for analysis of the data in the F8-culture filtrate pretreated group and the $\mathrm{H}_{2} \mathrm{O}$-pretreated control group. ${ }^{* *} p<0.01 ;{ }^{* * *} p<0.001$.

In addition to $\mathrm{Yu}-\mathrm{Nu}$ tomato, we also conducted field trials on Xiao-Nu in Alian District, Kaohsiung City. The results showed that much milder symptoms were observed on tomato cultivar Xiao-Nu pretreated with F8-culture filtrate than with $\mathrm{H}_{2} \mathrm{O}$ after planting in field for 2 months (Figure 6C,D). Collectively, our results indicated that F8-culture filtrate could induce effective resistance on different tomato cultivars against TYLCD in the field.

\section{Discussion}

The application of plant immunity inducers for crop protection is an environmentally sound approach, which can reduce the use of chemical pesticides to maintain healthy crops. The data presented in this study indicates that F8-culture filtrate is an effective method to induce tomato resistance against TYLCTHV both in the greenhouse and in the field (Figures 1 and 2), with no obvious decrease in tomato growth (Figure 3). In addition, we also revealed the immune pathway(s) induced by F8-culture filtrate-pretreated tomato before or 
after TYLCTHV infection, which provides important information for understanding how plants can effectively ward-off infection by WTBs.

In designing the F8-culture filtrate, we have considered the cost, stability, and the method for application in the field. Instead of direct application of microbe(s) in the field, we chose F8-culture filtrate for practical application. This is to minimize environmental conditions that may affect the plant-microbe interaction and reduce the efficacy of induced resistance. F8-culture filtrate is made from inexpensive vegetable broth cultured with Trichosporon sp., and can be stored as a liquid at $4{ }^{\circ} \mathrm{C}$ for 2 months or as a lyophilized powder at $4{ }^{\circ} \mathrm{C}$ for at least 1 year. The powdered F8-culture filtrate can be dissolved in water before application [62]. For practical application, we only treated tomato seedlings with F8-culture filtrate before planting them in field, and no additional work was needed to induce resistance thereafter. However, profound enhanced resistance was found on F8-culture filtrate-treated tomato in the field (Figure 6).

We previously reported that F8-polysaccharide-treated $N$. benthamiana induced a typical immune priming expression pattern in both $P R-1$ and $P R-2$ [62]. Intriguingly, although F8-culture filtrate induced early induction of two tomato SA-mediated immune marker genes, $P R-1$ and $P R-5$, only $P R-1$ showed the typical immune priming expression pattern (Figure $4 \mathrm{~A}$ ). The expression of $P R-5$ was induced by F8-culture filtrate, but the induction fold was less after TYLCTHV inoculation than in the plants with F8-culture filtrate pretreatment (Figure 4B). This suggests that F8-culture filtrate can trigger the early SA-mediated immune pathway but only induce part of the SA-mediated immune priming. Alternatively, because we detected the PR-5 expression at $4 \mathrm{dpi}$, at that time TYLCTHV may already express effector(s) to compromise part of the immune response.

Previous reports have indicated that callose deposition has been found to confine virus infection by limiting cell-to-cell movement [79-83], and the SA-mediated immune pathway plays an important role in pathogen-induced callose deposition in Arabidopsis [81,84]. Consistently, our data indicated that F8-culture filtrate mainly induced the SA-mediated immune pathway and more callose deposits were found on tomato pretreated with F8culture filtrate than with $\mathrm{H}_{2} \mathrm{O}$ (Figures $4 \mathrm{~A}$ and $5 \mathrm{D}$ ). In addition, the gene involved in callose synthesis, PMR4, was up-regulated only in plants pretreated with F8-culture filtrate after TYLCTHV inoculation at $4 \mathrm{dpi}$ (Figure 5F). Interestingly, the induction of callose depositions and PMR4 was not seen in plants pretreated with F8-culture filtrate before TYLCTHV inoculation (Figure 5B). This indicated that even though we did not detect the priming of callose depositions and PMR4 induction on F8-culture filtrate pretreated tomato before TYLCTHV inoculation, F8-culture filtrate primed the induction of tomato plants for callose depositions and PMR4 induction.

In comparison to expression of SA-mediated immune marker genes, only certain immune marker genes from the JA or ET pathways were induced in the F8-culture filtrate pretreated group as the expression of JA responsive gene, STH2, and ET responsive genes, ETR4 and Pti4, remained similar in all the treated groups. However, we found that a gene involved in synthesis of JA, OPR3, was induced at $24 \mathrm{hpt}$ after F8-culture filtrate treatment and at 4 dpi after TYLCTHV inoculation on F8-culture filtrate pretreated tomato (Figure 4C). For the ethylene-mediated immune pathway, we found the gene ETR4, which functions as an ethylene receptor in tomato [85], is only induced in F8-culture filtrate pretreated tomato at $24 \mathrm{hpt}$ (Figure 4E). This indicates inconsistent induction of JA- and ET-mediated immune marker genes. Notably, the induction of OPR3 and ETR4 was observed to be later than the induction of SA-mediated immune marker genes on F8-culture filtrate-treated tomato (Figure 4A,C,E). In addition, OPR3, but not ETR4, was induced after TYLCTHV inoculation (Figure 4C,E). The induction fold of OPR3 expression was higher at 4 dpi (4.1-fold) than at $24 \mathrm{hpt}$ (1.5-fold). This indicates that OPR3 also showed a slight priming expression pattern.

Collectively, our data indicate that F8-culture filtrate is an effective inducer of tomato defense against TYLCTHV. In addition, we found that distinct SA immunity was induced compared to our previous report on N. benthamiana [52] This indicates that F8-culture filtrate mainly induces priming of SA immune response; however, the downstream im- 
mune responses vary among different plants. Together, our findings provide important practical information for application of F8-culture filtrate for tomato resistance against TYLCTHV and also provide insights for further enhancing SA-mediated plant immunity against viruses.

Supplementary Materials: The following are available online at https: / www.mdpi.com/article / 10.3390/v13081434/s1, Table S1: primer sequences, Figure S1: disease index of Yu-Nu tomato inoculated with tomato yellow leaf curl Thailand virus (TYLCTHV), Figure S2: symptom of Yu-Nu tomato inoculated with tomato yellow leaf curl Thailand virus (TYLCTHV). Figure S3: fresh weight of $\mathrm{Yu}-\mathrm{Nu}$ tomato with $\mathrm{H}_{2} \mathrm{O}$ or F8-culture filtrate pretreatment.

Author Contributions: Conceptualization, H.-H.Y., Y.-S.C., and Y.T.; investigation, Y.-S.C. and Y.-H.C., methodology, H.-H.Y. and Y.-S.C.; resources, Y.-H.C. and C.-W.T.; supervision, H.-H.Y. and C.-W.T.; validation, Y.-S.C.; visualization, Y.-S.C. and Y.T.; writing-original draft preparation, H.-H.Y., Y.-S.C. and Y.T.; writing—review and editing, H.-H.Y., Y.-S.C., Y.T., and C.-W.T.; project administration, H.-H.Y. and C.-W.T.; funding acquisition, H.-H.Y. All authors have read and agreed to the published version of the manuscript.

Funding: This research was funded by Innovative Translational Agricultural Research Grant Number AS-KPQ-107-ITAR-07, AS-KPQ-108-ITAR-07, AS-KPQ-109-ITAR-07 and AS-KPQ-110-ITAR-08.

Institutional Review Board Statement: Not applicable.

Informed Consent Statement: Not applicable.

Data Availability Statement: The data supporting the findings of this study are available within the article and Supplementary Materials.

Acknowledgments: We would like to acknowledge the kind assistance of Wen-Ling Deng and Jen-Yu Tzeng, Department of Plant Pathology, National Chung Hsing University, in the field trial. We are also grateful to Miranda Loney for assistance with English editing.

Conflicts of Interest: The authors declare no conflict of interest.

\section{References}

1. Brasesco, F.; Asgedom, D.; Casari, G. Strategic Analysis and Intervention Plan for Fresh and Industrial Tomato in the Agro-Commodities Procurement Zone of the Pilot Integrated Agro-Industrial Park in Central-Eastern Oromia, Ethiopia; FAO: Addis Ababa, Ethiopia, 2019.

2. Prasad, A.; Sharma, N.; Hari-Gowthem, G.; Muthamilarasan, M.; Prasad, M. Tomato Yellow Leaf Curl Virus: Impact, Challenges, and Management. Trends Plant Sci. 2020, 25, 897-911. [CrossRef]

3. Makkouk, K.M.; Shehab, S.; Majdalani, S.E. Tomato Yellow Leaf Curl: Incidence, Yield Losses and Transmission in Lebanon. J. Phytopathol. 1979, 96, 263-267. [CrossRef]

4. Pico, M.B.; Diez, M.J.; Nuez, F. Viral diseases causing the greatest economic losses to the tomato crop. II. The Tomato yellow leaf curl virus-A review. Sci. Hortic. 1996, 67, 151-196. [CrossRef]

5. Varma, A.; Malathi, V.G. Emerging geminivirus problems: A serious threat to crop production. Ann. Appl. Biol. 2003, 142, 145-164. [CrossRef]

6. Yan, Z.; Wolters, A.-M.; Navas-Castillo, J.; Bai, Y. The Global Dimension of Tomato Yellow Leaf Curl Disease: Current Status and Breeding Perspectives. Microorganisms 2021, 9, 740. [CrossRef] [PubMed]

7. Moriones, E.; Navas-Castillo, J. Tomato yellow leaf curl virus, an emerging virus complex causing epidemics worldwide. Virus Res. 2000, 71, 123-134. [CrossRef]

8. Horowitz, A.R.; Kontsedalov, S.; Khasdan, V.; Ishaaya, I. Biotypes B and Q of Bemisia tabaci and their relevance to neonicotinoid and pyriproxyfen resistance. Arch. Insect Biochem. Physiol. 2005, 58, 216-225. [CrossRef] [PubMed]

9. Lapidot, M.; Karniel, U.; Gelbart, D.; Fogel, D.; Evenor, D.; Kutsher, Y.; Makhbash, Z.; Nahon, S.; Shlomo, H.; Chen, L.; et al. A Novel Route Controlling Begomovirus Resistance by the Messenger RNA Surveillance Factor Pelota. PLoS Genet. 2015, 11, e1005538. [CrossRef] [PubMed]

10. Czosnek, H.; Eybishtz, A.; Sade, D.; Gorovits, R.; Sobol, I.; Bejarano, E.; Rosas-Díaz, T.; Lozano-Durán, R. Discovering host genes involved in the infection by the Tomato Yellow Leaf Curl Virus complex and in the establishment of resistance to the virus using Tobacco Rattle Virus-based post transcriptional gene silencing. Viruses 2013, 5, 998-1022. [CrossRef]

11. Elbaz, M.; Hanson, P.; Fgaier, S.; Laarif, A. Evaluation of tomato entries with different combinations of resistance genes to tomato yellow leaf curl disease in Tunisia. Plant Breed. 2016, 135, 525-530. [CrossRef]

12. Anbinder, I.; Reuveni, M.; Azari, R.; Paran, I.; Nahon, S.; Shlomo, H.; Chen, L.; Lapidot, M.; Levin, I. Molecular dissection of Tomato leaf curl virus resistance in tomato line TY172 derived from Solanum peruvianum. Theor. Appl. Genet. 2009, 119, 519-530. [CrossRef] [PubMed] 
13. Faal, P.G.; Farsi, M.; Seifi, A.; Kakhki, A.M. Virus-induced CRISPR-Cas9 system improved resistance against tomato yellow leaf curl virus. Mol. Biol. Rep. 2020, 47, 3369-3376. [CrossRef] [PubMed]

14. Fuentes, A.; Carlos, N.; Ruiz, Y.; Callard, D.; Sánchez, Y.; Ochagavía, M.E.; Seguin, J.; Malpica-López, N.; Hohn, T.; Lecca, M.R.; et al. Field Trial and Molecular Characterization of RNAi-Transgenic Tomato Plants That Exhibit Resistance to Tomato Yellow Leaf Curl Geminivirus. Mol. Plant Microbe Interact. 2016, 29, 197-209. [CrossRef] [PubMed]

15. Tzean, Y.; Chang, H.-H.; Tu, T.-C.; Hou, B.H.; Chen, H.-M.; Chiu, Y.-S.; Chou, W.-Y.; Chang, L.; Yeh, H.-H. Engineering Plant Resistance to Tomato Yellow Leaf Curl Thailand Virus Using a Phloem-Specific Promoter Expressing Hairpin RNA. Mol. Plant Microbe Interact. 2020, 33, 87-97. [CrossRef]

16. Asad, S.; Haris, W.A.A.; Bashir, A.; Zafar, Y.; Malik, K.A.; Malik, N.N.; Lichtenstein, C.P. Transgenic tobacco expressing geminiviral RNAs are resistant to the serious viral pathogen causing cotton leaf curl disease. Arch. Virol. 2003, 148, 2341-2352. [CrossRef]

17. Chellappan, P.; Masona, M.V.; Vanitharani, R.; Taylor, N.J.; Fauquet, C.M. Broad Spectrum Resistance to ssDNA Viruses Associated with Transgene-Induced Gene Silencing in Cassava. Plant Mol. Biol. 2004, 56, 601-611. [CrossRef]

18. Zhang, P.; Vanderschuren, H.; Futterer, J.; Gruissem, W. Resistance to cassava mosaic disease in transgenic cassava expressing antisense RNAs targeting virus replication genes. Plant Biotechnol. J. 2005, 3, 385-397. [CrossRef]

19. Bonfim, K.; Faria, J.C.; Nogueira, E.O.P.L.; Mendes, É.A.; Aragão, F.J.L. RNAi-Mediated Resistance to Bean golden mosaic virus in Genetically Engineered Common Bean (Phaseolus vulgaris). Mol. Plant Microbe Interact. 2007, 20, 717-726. [CrossRef]

20. Ramesh, S.; Mishra, A.; Praveen, S. Hairpin RNA-Mediated Strategies for Silencing of Tomato Leaf Curl Virus AC1 and AC4 Genes for Effective Resistance in Plants. Oligonucleotides 2007, 17, 251-257. [CrossRef]

21. Ammara, E.U.; Mansoor, S.; Saeed, M.; Amin, I.; Briddon, R.W.; Al-Sadi, A.M. RNA interference-based resistance in transgenic tomato plants against Tomato yellow leaf curl virus-Oman (TYLCV-OM) and its associated betasatellite. Virol. J. 2015, 12, 38. [CrossRef] [PubMed]

22. Lin, C.-Y.; Tsai, W.-S.; Ku, H.-M.; Jan, F.-J. Evaluation of DNA fragments covering the entire genome of a monopartite begomovirus for induction of viral resistance in transgenic plants via gene silencing. Transgenic Res. 2011, 21, 231-241. [CrossRef]

23. Fuentes, A.; Ramos, P.L.; Fiallo, E.; Callard, D.; Sánchez, Y.; Peral, R.; Rodríguez, R.; Pujol, M.; Fiallo-Olivé, E. Intron-hairpin RNA Derived from Replication Associated Protein C1 Gene Confers Immunity to Tomato Yellow Leaf Curl Virus Infection in Transgenic Tomato Plants. Transgenic Res. 2006, 15, 291-304. [CrossRef] [PubMed]

24. Yang, Y.; Sherwood, T.A.; Patte, C.P.; Hiebert, E.; Polston, J.E. Use of Tomato yellow leaf curl virus (TYLCV) Rep Gene Sequences to Engineer TYLCV Resistance in Tomato. Phytopathology 2004, 94, 490-496. [CrossRef] [PubMed]

25. Yu, X.; Feng, B.; He, P.; Shan, L. From Chaos to Harmony: Responses and Signaling upon Microbial Pattern Recognition. Annu. Rev. Phytopathol. 2017, 55, 109-137. [CrossRef] [PubMed]

26. Choi, H.W.; Klessig, D.F. DAMPs, MAMPs, and NAMPs in plant innate immunity. BMC Plant Biol. 2016, 16, 1-10. [CrossRef]

27. Schwessinger, B.; Ronald, P.C. Plant Innate Immunity: Perception of Conserved Microbial Signatures. Annu. Rev. Plant Biol. 2012, 63, 451-482. [CrossRef]

28. Smith, C.L. Distillation Control: An Engineering Perspective; John Wiley \& Sons: Hoboken, NJ, USA, $2012 ;$ pp. $70-135$.

29. Jones, J.D.G.; Dangl, J.L. The plant immune system. Nature 2006, 444, 323-329. [CrossRef]

30. Couto, D.; Zipfel, C. Regulation of pattern recognition receptor signalling in plants. Nat. Rev. Immunol. 2016, 16, 537-552. [CrossRef] [PubMed]

31. Spoel, S.; Dong, X. How do plants achieve immunity? Defence without specialized immune cells. Nat. Rev. Immunol. 2012, 12, 89-100. [CrossRef] [PubMed]

32. Cui, W.; Parker, L.L. A time-resolved luminescence biosensor assay for anaplastic lymphoma kinase (ALK) activity. Chem. Commun. 2014, 51, 362-365. [CrossRef] [PubMed]

33. Alazem, M.; Lin, N. Roles of plant hormones in the regulation of host-virus interactions. Mol. Plant Pathol. 2015, 16, 529-540. [CrossRef]

34. Asai, T.; Tena, G.; Plotnikova, J.; Willmann, M.R.; Chiu, W.-L.; Gomez-Gomez, L.; Boller, T.; Ausubel, F.M.; Sheen, J. MAP kinase signalling cascade in Arabidopsis innate immunity. Nat. Cell Biol. 2002, 415, 977-983. [CrossRef]

35. Ausubel, F.M. Are innate immune signaling pathways in plants and animals conserved? Nat. Immunol. 2005, 6, 973-979. [CrossRef] [PubMed]

36. Boller, T.; Felix, G. A Renaissance of Elicitors: Perception of Microbe-Associated Molecular Patterns and Danger Signals by Pattern-Recognition Receptors. Annu. Rev. Plant Biol. 2009, 60, 379-406. [CrossRef] [PubMed]

37. Pitzschke, A.; Djamei, A.; Teige, M.; Hirt, H. VIP1 response elements mediate mitogen-activated protein kinase 3-induced stress gene expression. Proc. Natl. Acad. Sci. USA 2009, 106, 18414-18419. [CrossRef]

38. Nicaise, V. Crop immunity against viruses: Outcomes and future challenges. Front. Plant Sci. 2014, 5, 660. [CrossRef]

39. Zhou, J.-M.; Chai, J. Plant pathogenic bacterial type III effectors subdue host responses. Curr. Opin. Microbiol. 2008, 11, 179-185. [CrossRef]

40. Zhang, J.; Zhou, J.-M. Plant Immunity Triggered by Microbial Molecular Signatures. Mol. Plant 2010, 3, 783-793. [CrossRef]

41. Toruño, T.Y.; Stergiopoulos, I.; Coaker, G. Plant-Pathogen Effectors: Cellular Probes Interfering with Plant Defenses in Spatial and Temporal Manners. Annu. Rev. Phytopathol. 2016, 54, 419-441. [CrossRef] [PubMed]

42. Grant, S.R.; Fisher, E.J.; Chang, J.H.; Mole, B.M.; Dangl, J.L. Subterfuge and Manipulation: Type III Effector Proteins of Phytopathogenic Bacteria. Annu. Rev. Microbiol. 2006, 60, 425-449. [CrossRef] 
43. Abramovitch, R.; Janjusevic, R.; Stebbins, E.; Martin, G.B. Type III effector AvrPtoB requires intrinsic E3 ubiquitin ligase activity to suppress plant cell death and immunity. Proc. Natl. Acad. Sci. USA 2006, 103, 2851-2856. [CrossRef] [PubMed]

44. Jacob, F.; Vernaldi, S.; Maekawa, T. Evolution and Conservation of Plant NLR Functions. Front. Immunol. 2013, 4, 297. [CrossRef] [PubMed]

45. Tsuda, K.; Katagiri, F. Comparing signaling mechanisms engaged in pattern-triggered and effector-triggered immunity. Curr. Opin. Plant Biol. 2010, 13, 459-465. [CrossRef] [PubMed]

46. Nishimura, M.; Dangl, J.L. Arabidopsis and the plant immune system. Plant J. 2010, 61, 1053-1066. [CrossRef]

47. Dangl, J.L.; Horvath, D.M.; Staskawicz, B.J. Pivoting the Plant Immune System from Dissection to Deployment. Science 2013, 341, 746-751. [CrossRef]

48. Chen, M.; Zeng, H.; Qiu, D.; Guo, L.; Yang, X.; Shi, H.; Zhou, T.; Zhao, J. Purification and Characterization of a Novel Hypersensitive Response-Inducing Elicitor from Magnaporthe oryzae that Triggers Defense Response in Rice. PLoS ONE 2012, 7, e37654. [CrossRef]

49. Chen, M.; Zhang, C.; Zi, Q.; Qiu, D.; Liu, W.; Zeng, H. A novel elicitor identified from Magnaporthe oryzae triggers defense responses in tobacco and rice. Plant Cell Rep. 2014, 33, 1865-1879. [CrossRef]

50. Wang, L.; Yang, X.; Zeng, H.; Qiu, D.; Guo, L.; Liu, Z. Extracellular expression of protein elicitor PeaT1 in Bacillus subtilis to enhance drought tolerance and growth in wheat. Sheng Wu Gong Cheng Xue Bao 2011, 27, 1355-1362. [PubMed]

51. Wang, N.; Liu, M.; Guo, L.; Yang, X.; Qiu, D. A Novel Protein Elicitor (PeBA1) from Bacillus amyloliquefaciens NC6 Induces Systemic Resistance in Tobacco. Int. J. Biol. Sci. 2016, 12, 757-767. [CrossRef]

52. Zhang, Y.; Yang, X.; Zeng, H.; Guo, L.; Yuan, J.; Qiu, D. Fungal elicitor protein PebC1 from Botrytis cinerea improves disease resistance in Arabidopsis thaliana. Biotechnol. Lett. 2014, 36, 1069-1078. [CrossRef]

53. Zhang, Y.; Zhang, Y.; Qiu, D.; Zeng, H.; Guo, L.; Yang, X. BcGs1, a glycoprotein from Botrytis cinerea, elicits defence response and improves disease resistance in host plants. Biochem. Biophys. Res. Commun. 2015, 457, 627-634. [CrossRef]

54. Pichyangkura, R.; Chadchawan, S. Biostimulant activity of chitosan in horticulture. Sci. Hortic. 2015, 196, 49-65. [CrossRef]

55. Van Loon, L.C.; Rep, M.; Pieterse, C.M.J. Significance of Inducible Defense-related Proteins in Infected Plants. Annu. Rev. Phytopathol. 2006, 44, 135-162. [CrossRef] [PubMed]

56. Djonović, S.; Pozo, M.J.; Dangott, L.J.; Howell, C.R.; Kenerley, C.M. Sm1, a Proteinaceous Elicitor Secreted by the Biocontrol Fungus Trichoderma virens Induces Plant Defense Responses and Systemic Resistance. Mol. Plant Microbe Interact. 2006, 19, 838-853. [CrossRef] [PubMed]

57. Perazzolli, M.; Roatti, B.; Bozza, E.; Pertot, I. Trichoderma harzianum T39 induces resistance against downy mildew by priming for defense without costs for grapevine. Biol. Control 2011, 58, 74-82. [CrossRef]

58. Seidl, V.; Marchetti, M.; Schandl, R.; Allmaier, G.; Kubicek, C.P.; Marchetti-Deschmann, M. Epl1, the major secreted protein of Hypocrea atroviridis on glucose, is a member of a strongly conserved protein family comprising plant defense response elicitors. FEBS J. 2006, 273, 4346-4359. [CrossRef] [PubMed]

59. Tsai, W.-A.; Weng, S.-H.; Chen, M.-C.; Lin, J.-S.; Tsai, W.-S. Priming of Plant Resistance to Heat Stress and Tomato Yellow Leaf Curl Thailand Virus With Plant-Derived Materials. Front. Plant Sci. 2019, 10, 906. [CrossRef] [PubMed]

60. Heijari, J.; Nerg, A.; Kainulainen, P.; Viiri, H.; Vuorinen, M.; Holopainen, J. Application of methyl jasmonate reduces growth but increases chemical defence and resistance against Hylobius abietis in Scots pine seedlings. Entomol. Exp. Appl. 2005, 115, 117-124. [CrossRef]

61. Boughton, A.J.; Hoover, K.; Felton, G.W. Impact of chemical elicitor applications on greenhouse tomato plants and population growth of the green peach aphid, Myzus persicae. Entomol. Exp. Appl. 2006, 120, 175-188. [CrossRef]

62. Chiu, Y.-S.; Chen, P.-Y.; Kuan, T.; Wang, P.-C.; Chen, Y.-J.; Yang, Y.-L.; Yeh, H.-H. A Polysaccharide Derived from a Trichosporon sp. Culture Strongly Primes Plant Resistance to Viruses. Mol. Plant Microbe Interact. 2018, 31, 1257-1270. [CrossRef]

63. Li, T.; Huang, Y.; Xu, Z.-S.; Wang, F.; Xiong, A.-S. Salicylic acid-induced differential resistance to the Tomato yellow leaf curl virus among resistant and susceptible tomato cultivars. BMC Plant Biol. 2019, 19, 173. [CrossRef]

64. Shih, S.L.; Tsai, W.S.; Lee, L.M.; Wang, J.T.; Green, S.K.; Kenyon, L. First Report of Tomato yellow leaf curl Thailand virus Associated with Pepper Leaf Curl Disease in Taiwan. Plant Dis. 2010, 94, 637. [CrossRef]

65. Jan, F.-J.; Green, S.K.; Shih, S.L.; Lee, L.M.; Ito, H.; Kimbara, J.; Hosoi, K.; Tsai, W.S. First Report of Tomato yellow leaf curl Thailand virus in Taiwan. Plant Dis. 2007, 91, 1363. [CrossRef]

66. Tsai, W.S.; Shih, S.L.; Kenyon, L.; Green, S.K.; Jan, F.-J. Temporal distribution and pathogenicity of the predominant tomatoinfecting begomoviruses in Taiwan. Plant Pathol. 2011, 60, 787-799. [CrossRef]

67. Weng, S.; Tsai, W.; Kenyon, L.; Tsai, C.-W. Different transmission efficiencies may drive displacement of tomato begomoviruses in the fields in Taiwan. Ann. Appl. Biol. 2015, 166, 321-330. [CrossRef]

68. Hu, F.-Y.; Mou, D.-F.; Tsai, C.-W. Evaluation of barrier plants for the cultural control of tomato yellow leaf curl disease. J. Asia-Pac. Entomol. 2020, 23, 132-137. [CrossRef]

69. Li, W.-H.; Mou, D.-F.; Hsieh, C.-K.; Weng, S.-H.; Tsai, W.-S.; Tsai, C.-W. Vector Transmission of Tomato Yellow Leaf Curl Thailand Virus by the Whitefly Bemisia tabaci: Circulative or Propagative? Insects 2021, 12, 181. [CrossRef] [PubMed]

70. Chang, S.; Puryear, J.; Cairney, J. A simple and efficient method for isolating RNA from pine trees. Plant Mol. Biol. Rep. 1993, 11, 113-116. [CrossRef] 
71. Anfoka, G.; Moshe, A.; Fridman, L.; Amrani, L.; Rotem, O.; Kolot, M.; Zeidan, M.; Czosnek, H.; Gorovits, R. Tomato yellow leaf curl virus infection mitigates the heat stress response of plants grown at high temperatures. Sci. Rep. 2016, 6, 19715. [CrossRef] [PubMed]

72. Moshe, A.; Gorovits, R.; Liu, Y.; Czosnek, H. Tomato plant cell death induced by inhibition of HSP90 is alleviated by Tomato yellow leaf curl virus infection. Mol. Plant Pathol. 2016, 17, 247-260. [CrossRef] [PubMed]

73. Ning, W.; Shi, X.; Liu, B.; Pan, H.; Wei, W.; Zeng, Y.; Sun, X.; Xie, W.; Wang, S.; Wu, Q.; et al. Transmission of Tomato Yellow Leaf Curl Virus by Bemisia tabaci as Affected by Whitefly Sex and Biotype. Sci. Rep. 2015, 5, srep10744. [CrossRef]

74. Sun, Y.-C.; Pan, L.-L.; Ying, F.-Z.; Li, P.; Wang, X.-W.; Liu, S.-S. Jasmonic acid-related resistance in tomato mediates interactions between whitefly and whitefly-transmitted virus. Sci. Rep. 2017, 7, 566. [CrossRef]

75. Liu, Y.; Du, M.; Deng, L.; Shen, J.; Fang, M.; Chen, Q.; Lu, Y.; Wang, Q.; Li, C.; Zhai, Q. MYC2 Regulates the Termination of Jasmonate Signaling via an Autoregulatory Negative Feedback Loop. Plant Cell 2019, 31, 106-127. [CrossRef]

76. Martín-Rodríguez, J.Á.; León-Morcillo, R.; Vierheilig, H.; Ocampo, J.A.; Ludwig-Müller, J.; García-Garrido, J.M. Ethylenedependent/ethylene-independent ABA regulation of tomato plants colonized by arbuscular mycorrhiza fungi. New Phytol. 2011, 190, 193-205. [CrossRef]

77. Li, R.; Wang, L.; Li, Y.; Zhao, R.; Zhang, Y.; Sheng, J.; Ma, P.; Shen, L. Knockout of SINPR1 enhances tomato plants resistance against Botrytis cinerea by modulating ROS homeostasis and JA/ET signaling pathways. Physiol. Plant. 2020, 170, 569-579. [CrossRef]

78. Jacobs, A.K.; Lipka, V.; Burton, R.; Panstruga, R.; Strizhov, N.; Schulze-Lefert, P.; Fincher, G.B. An Arabidopsis Callose Synthase, GSL5, Is Required for Wound and Papillary Callose Formation. Plant Cell 2003, 15, 2503-2513. [CrossRef] [PubMed]

79. Alazem, M.; Lin, N.-S. Antiviral Roles of Abscisic Acid in Plants. Front. Plant Sci. 2017, 8, 1760. [CrossRef] [PubMed]

80. Chen, X.-Y.; Kim, J.-Y. Callose synthesis in higher plants. Plant Signal. Behav. 2009, 4, 489-492. [CrossRef] [PubMed]

81. Epel, B.L. Plant viruses spread by diffusion on ER-associated movement-protein-rafts through plasmodesmata gated by viral induced host beta-1,3-glucanases. Semin. Cell Dev. Biol. 2009, 20, 1074-1081.

82. Hofmann, J.; Banora, M.; De Almeida-Engler, J.; Grundler, F.M.W. The Role of Callose Deposition Along Plasmodesmata in Nematode Feeding Sites. Mol. Plant Microbe Interact. 2010, 23, 549-557. [CrossRef] [PubMed]

83. Li, W.; Zhao, Y.; Liu, C.; Yao, G.; Wu, S.; Hou, C.; Zhang, M.; Wang, D. Callose deposition at plasmodesmata is a critical factor in restricting the cell-to-cell movement of Soybean mosaic virus. Plant Cell Rep. 2012, 31, 905-916. [CrossRef] [PubMed]

84. Wang, X.; Sager, R.; Cui, W.; Zhang, C.; Lu, H.; Lee, J.Y. Salicylic Acid Regulates Plasmodesmata Closure during Innate Immune Responses in Arabidopsis. Plant Cell 2013, 25, 2315-2329. [CrossRef] [PubMed]

85. Kevany, B.M.; Tieman, D.M.; Taylor, M.G.; Cin, V.D.; Klee, H.J. Ethylene receptor degradation controls the timing of ripening in tomato fruit. Plant J. 2007, 51, 458-467. [CrossRef] [PubMed] 